\title{
Degradation of Semiconductor Manufacturing Wastewater by Using a Novel Magnetic Composite $\mathrm{TiO}_{2} / \mathrm{Fe}_{3} \mathrm{O}_{4}$ Photoreactor Design
}

\author{
Chen-Yu Chang ${ }^{1}$ and Yung-Hsu Hsieh ${ }^{2}$ \\ ${ }^{1}$ Center of General Education, National Taitung College, 889 Jhengci N. Rdoa, Taitung City 95045, Taiwan \\ ${ }^{2}$ Department of Environmental Engineering, National Chung Hsing University, 250 Kuo-Kung Road, Taichung City 402, Taiwan
}

Correspondence should be addressed to Chen-Yu Chang, cyc1136@ntc.edu.tw

Received 13 February 2012; Revised 25 April 2012; Accepted 26 April 2012

Academic Editor: Jiaguo Yu

Copyright (C) 2012 C.-Y. Chang and Y.-H. Hsieh. This is an open access article distributed under the Creative Commons Attribution License, which permits unrestricted use, distribution, and reproduction in any medium, provided the original work is properly cited.

\begin{abstract}
The purpose of this research is to develop a photocatalytic $\mathrm{TiO}_{2}$ that can be activated by visible light and can be conveniently recollected for reusing. This research synthesizes the 20 to $40 \mathrm{~nm} \mathrm{TiO} / \mathrm{Fe}_{3} \mathrm{O}_{4}$ particles with magnetization of $5.8 \mathrm{emu} / \mathrm{g}$ using the modified sol-gel method followed by $500^{\circ} \mathrm{C}$ calcinations. The experiment verified that visible fluorescent light (VFL, contains no UV-A) could activate the photocatalytic activity of $\mathrm{TiO}_{2} / \mathrm{Fe}_{3} \mathrm{O}_{4}$ particles as did ultraviolet A light (UV-A, 360 nm). Regular magnets can be used to separate $\mathrm{TiO}_{2} / \mathrm{Fe}_{3} \mathrm{O}_{4}$ particles from solution. The results indicate that VFL-sirradiated $\mathrm{TiO}_{2} / \mathrm{Fe}_{3} \mathrm{O}_{4}$ particles could decompose isopropanol (IPA) in the absence of UV-A and the issue of $\mathrm{TiO}_{2} / \mathrm{Fe}_{3} \mathrm{O}_{4}$ recollection from water for reusing is also resolved.
\end{abstract}

\section{Introduction}

In the typical semiconductor manufacturing processes, a large amount of IPA is used for wafer cleaning. The wafer cleaning processes invariably generate a large quantity of wastewater that contains refractory and complex organic compounds. Not only do these organic compounds pose direct or indirect harm to the liver, kidney, central nervous system, and skin, some of them have already been verified as carcinogen, teratogenic agent, and gene mutagen for humans. Traditional wastewater treatment approaches involving physical-chemical decomposition or microorganisms have shown only limited efficiencies [1]. Many advanced oxidation processes (AOPs) have been extensively utilized for the decomposition of hazardous or recalcitrant pollutants in the environment. In recent years, $\mathrm{TiO}_{2}$ has attracted much attention because of the low price and steady and high photocatalytic activation [1-4]. However, requirement of using UV light to activate $\mathrm{TiO}_{2}$ photocatalyst and difficultly to recover the photocatalyst are still major limitationly for degradation of environmental pollutants $[5,6]$. There are many types of conventional methods to modify quality of photocatalyst. One of them is $\mathrm{TiO}_{2}$ photocatalyst doped by the transition metal [7-22]. It makes the defect of the structure of $\mathrm{TiO}_{2}$ and produces the lower energy gap. Therefore, just less energy reacts with $\mathrm{O}_{2}$ and $\mathrm{H}_{2} \mathrm{O}$ in the environment to form the excited electron and holes. As a consequence, the absorbed spectrum of $\mathrm{TiO}_{2}$ can shift into the region of visible light. $\mathrm{V}, \mathrm{Fe}, \mathrm{Cr}, \mathrm{Ni}, \mathrm{Cu}$, and other transition metals are well-known to be doped into $\mathrm{TiO}_{2}$ thin film to shift the band gap to visible light. Producing visible-light-activated $\mathrm{TiO}_{2}$ powder for easy recovery can be beneficial. Iron enhances $\mathrm{TiO}_{2}$ visible light absorption and thus increases its photocatalytic activity. Previous researches have reported that iron-based nanoparticles have been superparamagnetic $[1,18,23,24]$ and have been coated with organic polymers such as porphyrin and other dyes $[6,25$, 26] or other inorganic elements such as $\mathrm{N}$ and $\mathrm{H}$ [27-29] and other methods $[29,30]$. This research uses sol-gel method to add $\mathrm{Fe}_{3} \mathrm{O}_{4}$ during $\mathrm{TiO}_{2}$ synthesis and then uses visiblelight-irradiated $\mathrm{TiO}_{2} / \mathrm{Fe}_{3} \mathrm{O}_{4}$ to conduct photodegradation effect on IPA. The photodegradation efficiency of IPA and 
the recovery rate of photocatalyst will be also evaluated in this study.

\section{Experimental/Materials and Methods}

2.1. Preparation of Photocatalyst. In this study, the $\mathrm{TiO}_{2} /$ $\mathrm{Fe}_{3} \mathrm{O}_{4}$ complex was prepared using the modified sol-gel method [4]. The sol-gel process is one of the versatile methods to prepare high-pure and nanosize materials shaped as powders or coatings. This approach does not need complicated instruments such as chemical vapor deposition. It provides a simple and easy method to synthesize nanosize photocatalysts. First, soluble $\mathrm{TiO}_{2}$ precursor powder was prepared using a mixture of tetraisopropyl orthotitanate $\left(\mathrm{Ti}\left(\mathrm{OC}_{3} \mathrm{H}_{7}\right)_{4}\right)$ (TTIP, $>98 \%$, Merck Co. $)$, 2-propanol (>99.7\%, JT. Baker), and acetic acid (>99.9\%, JT. Baker). Then, the mixed solutions were stirred for $24 \mathrm{~h}$ and dried at $105^{\circ} \mathrm{C}$ followed by $150^{\circ} \mathrm{C}$ for $1 \mathrm{~h}$, respectively. The dried gel was then pulverized into powder and calcinated in the high-temperature oven. The parameters employed to control the preparation of the catalyst include 2-propanol, acetic acid (TTIP was fixed), calcinations time, and calcinations temperature. The orthogonal arrays in the design of the experimental method proposed by Taguchi were adopted to conduct the multiple-factor experiment. Second, the above-prepared $\mathrm{TiO}_{2}$ powder was directly mixed with iron oxide $\left(\mathrm{Fe}_{3} \mathrm{O}_{4}\right.$, $>98 \%$, Aldrich) and $\mathrm{Fe}_{3} \mathrm{O}_{4} / \mathrm{TiO}_{2}$ at the designed molar ratio of 0.1 . Then, the mixed solutions were stirred for $1 \mathrm{~h}$ and dried at $105^{\circ} \mathrm{C}$ for $1 \mathrm{~h}$. The conversion rate of IPA in this experiment was employed to identify the optimal conditions for assembly. The reactor containing $\mathrm{TiO}_{2} / \mathrm{Fe}_{3} \mathrm{O}_{4}$ complexes was irradiated with $419 \mathrm{~nm}$ fluorescent lamps to undergo the batch photocatalytic degradation experiment.

2.2. Photoelectrocatalytic Procedure. The liquid-phase photoelectrocatalytic system consisted of 16 VFLs (Rayonet Model RPR 100 Photochemistry Reactor, the Southern New England Ultraviolet Company, fluorescent lamps $\lambda_{\max }=419 \mathrm{~nm}$, intensity $=724 \mathrm{~lx}$ ), a completely mixing reactor, and an air compressor for aeration and stirring use, and a peristaltic pump was used to draw sample into the reactor for the continuous refluxing batch experiments and the flow rate controlled at $300 \mathrm{~mL} \mathrm{~min}{ }^{-1}$. The apparatus is illustrated in Figure 1. The experiment used the batch reaction system with the aqueous sample of $850 \mathrm{~mL}$, and the controlled parameters were $\mathrm{pH}$ values and the amount of photocatalyst. A gas chromatography equipped with flame ionization detector (GC-FID; Agilent Co., Model HP6890 Series) and chromatography column $(60 \mathrm{~m} \times 0.32 \mathrm{~mm} \times 0.5 \mu \mathrm{m}$, Agilent HPINNOWax) were employed to determine the concentration of IPA. Total organic carbon instruments (TOC; Shimadzu, Japan, Model TOC-VCSN) were employed for the analysis of the experiment to investigate the variations of the residual rates and the mineralization rates under the parameters described above. Besides, all the other chemicals were of either analytical or reagent grade. The deionized water $\left(\geq 18 \mathrm{M} \Omega \mathrm{cm}^{-1}\right.$ ) used for preparing the chemical solutions was processed by the Milli-Ultrapure R/O System (Millipore, USA) to ensure the quality of the prepared solution.

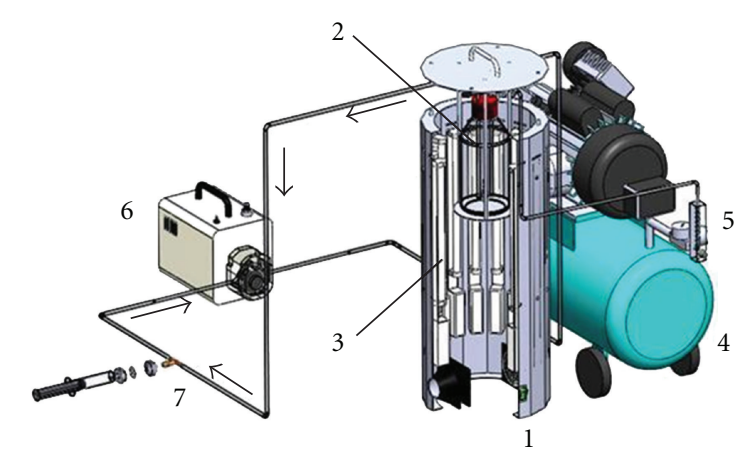
(1) Photocatalystic chamber
(2) Reactor
(3) Visible light
(5) Mass flow meter
(6) Peristaltic pump
(4) Air compressor
(7) Sampling syringe

FIGURE 1: Schematic diagram of continuous photocatalytic degradation system.

\section{Results and Discussion}

3.1. Optimal Preparation of Photocatalysts Using Taguchi Method. The controlling factors, which include 2-propanol $(0.08,0.16$, and $0.32 \mathrm{~mol})$, acetic acid $(0.08,0.16$, and $0.32 \mathrm{~mol})$, calcinations temperature $\left(400,500\right.$, and $\left.600^{\circ} \mathrm{C}\right)$, and calcinations time $(90,120$, and $180 \mathrm{~min})$, were chosen according to the work of Cheng et al. [4]. The orthogonal arrays in the experimental design proposed by Zhang [31] were adopted to conduct the multiple-factor experiment and obtain the best combination of conditions for experimental photocatalytic conversion of IPA. The four parameters of various levels yield 9 different combinations as summarized in the $\mathrm{L}_{9}$ orthogonal array table. Different photocatalysts were prepared according to different combinations of controlling factors for conducting the heterogeneous photocatalytic reactions to obtain the conversion rates of IPA. The IPA conversion rates thus obtained were then statistically analyzed by the $F$ test to determine the significance and variability of each factor. The result showed that, among the factors, calcinations temperature had the greatest effect on conversion rate of IPA in the photocatalysis system (42.06\%), followed by calcinations time $(27.14 \%)$, the amount of 2 propanol $(14.86 \%)$, and, finally, the amount of acetic acid $(14.67 \%)$. In general, the effect of calcination temperature was more significant due to its function in removing impurities and increasing crystal strength. Table 1 shows the contributions and major effects of different parameters. The optimal preparation condition of $\mathrm{TiO}_{2}$ catalyst was achieved under water 2-propanol of $0.08 \mathrm{~mol}$, acetic acid of $0.32 \mathrm{~mol}$ (i.e., TTIP/2-proanol/acetic acid with a molar ratio of $1: 2: 8$ ), calcinations temperature of $500^{\circ} \mathrm{C}$, and calcinations time of $90 \mathrm{~min}$. The $\mathrm{TiO}_{2}$ was prepared at the above optimal experimental conditions. Then, the above prepared $\mathrm{TiO}_{2}$ powder was directly mixed with $\mathrm{Fe}_{3} \mathrm{O}_{4}$ and $\mathrm{Fe}_{3} \mathrm{O}_{4} / \mathrm{TiO}_{2}$ at the designed molar ratio of 0.1 , and the mixed solutions were stirred for $1 \mathrm{~h}$ and dried at $105^{\circ} \mathrm{C}$ for $1 \mathrm{~h}$. The solid was calcinated in an atmospheric oven heated to $200^{\circ} \mathrm{C}$ at 
TABLE 1: Response of parameters in $\mathrm{L}_{9}$ table.

\begin{tabular}{lcccc}
\hline Factors & $\begin{array}{c}\text { 2-propanol } \\
(\mathrm{mol})\end{array}$ & $\begin{array}{c}\text { Acetic acid } \\
(\mathrm{mol})\end{array}$ & $\begin{array}{c}\text { Calcination } \\
\text { temperature } \\
\left({ }^{\circ} \mathrm{C}\right)\end{array}$ & $\begin{array}{c}\text { Calcination } \\
\text { time }(\mathrm{min})\end{array}$ \\
\hline Level 1 & 61.89 & 48.52 & 52.98 & 67.51 \\
Level 2 & 47.54 & 62.11 & 36.67 & 40.64 \\
Level 3 & 59.19 & 58.03 & 78.64 & 60.08 \\
Main effect & 14.86 & 14.67 & 42.06 & 27.14 \\
\hline
\end{tabular}

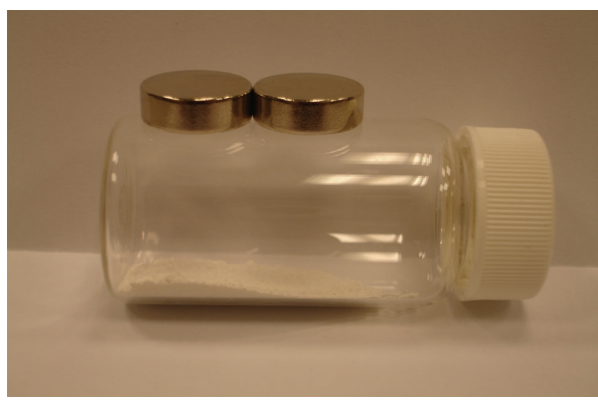

FIgUre 2: The appearance of $\mathrm{TiO}_{2}$ particles.

the rate of $5^{\circ} \mathrm{C} / \mathrm{min}$, held for $1 \mathrm{~h}$ and reheated to $500^{\circ} \mathrm{C}$ at the rate of $5^{\circ} \mathrm{C} / \mathrm{min}$, and then held for another $3 \mathrm{~h}$. The solid was grounded into powder, washed with distilled water, and then dried at $60^{\circ} \mathrm{C}$.

3.2. Properties Analysis of Photocatalysts. The photocatalyst prepared by the modified sol-gel method under the optimal conditions described above and the magnetism was tested and is shown in Figures 2, 3, and 4. As can be seen, the pure $\mathrm{Fe}_{3} \mathrm{O}_{4}$ particles and $\mathrm{TiO}_{2} / \mathrm{Fe}_{3} \mathrm{O}_{4}$ composite catalyst also had good magenetism. The magnetization curve of $\mathrm{TiO}_{2} / \mathrm{Fe}_{3} \mathrm{O}_{4}$ composite catalyst was measured with Superconducting Quantum Interference Device Magnetometer (SQUID; SQUID-PMS5, Quantum Design Corp.), and Figure 5 illustrates the saturation magnetization intensity of $\mathrm{TiO}_{2} / \mathrm{Fe}_{3} \mathrm{O}_{4}$ composite catalyst was $5.8 \mathrm{emu} / \mathrm{g}$. The field-emission scanning electron micrographs (FE-SEM, JSM-6700F, JEOL, Japan) of $\mathrm{TiO}_{2} / \mathrm{Fe}_{3} \mathrm{O}_{4}$ composite catalyst were shown in Figure 6, and they clearly displayed that the particle was little irregular and the size was about 20-40 nm. Anatase $\mathrm{TiO}_{2}$ containing $\mathrm{Fe}_{3} \mathrm{O}_{4}$ was obtained and analyzed by the $\mathrm{X}$-ray diffractometer (XRD) and compared with the JCPDS database (no. 84-1286 and 89-4319) (Figure 7). The X-ray diffractometer (XRD, MAC MXTIII) was used to examine the crystals form.

3.3. Adsorption Effect. In this study, the adsorption ability of the $\mathrm{TiO}_{2} / \mathrm{Fe}_{3} \mathrm{O}_{4}$ composite catalyst has been studied at varied $\mathrm{pH}(4,7$, and 10$)$ with $30 \mathrm{mg} \mathrm{L}^{-1}$ IPA without any irradiation at temperature of $25^{\circ} \mathrm{C}$ in the reaction chamber for 240 minutes. The adsorption ability for the $\mathrm{TiO}_{2} / \mathrm{Fe}_{3} \mathrm{O}_{4}$ composite catalyst was weak under alkaline and neutral conditions but not significantly different. Because all of the adsorption rates were less than $1 \%$, the effect of

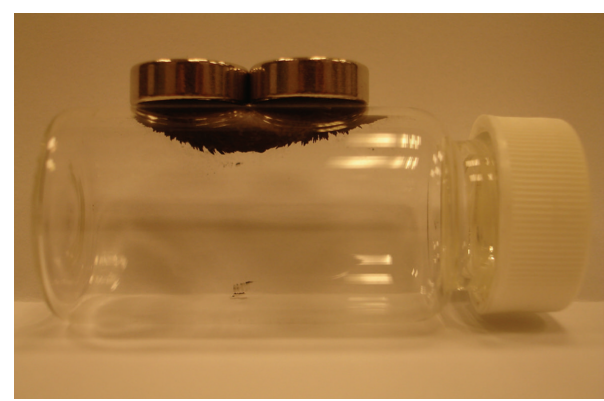

Figure 3: The appearance of $\mathrm{Fe}_{3} \mathrm{O}_{4}$ particles.

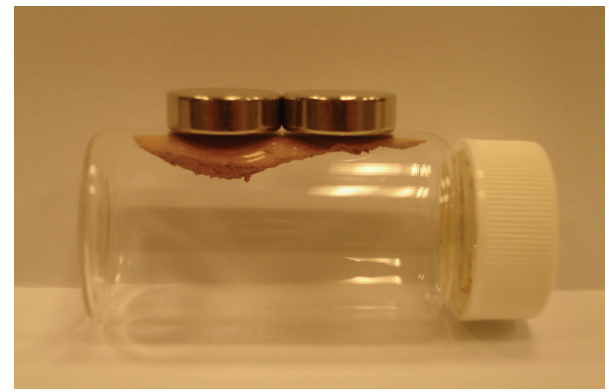

FIgURE 4: The appearance of $\mathrm{TiO}_{2} / \mathrm{Fe}_{3} \mathrm{O}_{4}$ particles.

adsorption was not taken into consideration in the following experiments, which did not affect the interpretation of the data acquired.

3.4. Photoelectrocatalytic Tests. Because the photolytic efficiency of UV irradiation treated with IPA was less than $2 \%$ in 3 replicates test, therefore the part experiment was not taken into comparing in the subsequent experiments. The photoactivity indicator of the $\mathrm{TiO}_{2} / \mathrm{Fe}_{3} \mathrm{O}_{4}$ composite catalyst was investigated by the conversion rate of IPA. The $2.0 \mathrm{~g} \mathrm{TiO}_{2} / \mathrm{Fe}_{3} \mathrm{O}_{4}$ composite catalyst was used to react with $30 \mathrm{mg} \mathrm{L}^{-1}$ IPA under $3.0 \mathrm{~mW} \mathrm{~cm}^{-2}, 365 \mathrm{~nm}$ UV light (UVA), $724 \mathrm{~lx}$ VFL at $\mathrm{pH} 7$ for $240 \mathrm{~min}$. The results are illustrated in Figure 8, and the destruction removal efficiency (DRE) of the $\mathrm{TiO}_{2} / \mathrm{Fe}_{3} \mathrm{O}_{4}$ composite catalyst on the conversion of IPA was higher than the $\mathrm{TiO}_{2}$ catalyst alone. Evidence reveals that the system of the $\mathrm{TiO}_{2} / \mathrm{Fe}_{3} \mathrm{O}_{4}$ complexes has significantly high efficiency of photocatalytic degradation than $\mathrm{TiO}_{2}$ only.

From the experimental data, we could find and understand that the $\mathrm{TiO}_{2}$ and $\mathrm{TiO}_{2} / \mathrm{Fe}_{3} \mathrm{O}_{4}$ composites had good performance under UV irradiation because UV light was with higher energy, but this experiment verified that visible fluorescent light could activate the photocatalytic activity of $\mathrm{TiO}_{2} / \mathrm{Fe}_{3} \mathrm{O}_{4}$ particles as did ultraviolet $\mathrm{A}$ light. The result showed that the $\mathrm{TiO}_{2} / \mathrm{Fe}_{3} \mathrm{O}_{4}$ composite catalyst also had good destruction rate for IPA under visible light, and this evidence revealed that the system of the $\mathrm{TiO}_{2} / \mathrm{Fe}_{3} \mathrm{O}_{4}$ composite catalyst could be used to treat organic pollutants in practical wastewater treatment factories.

3.5. $p H$ Effect. Although there was no significant variation of adsorption experiments under different $\mathrm{pH}$ values, there 


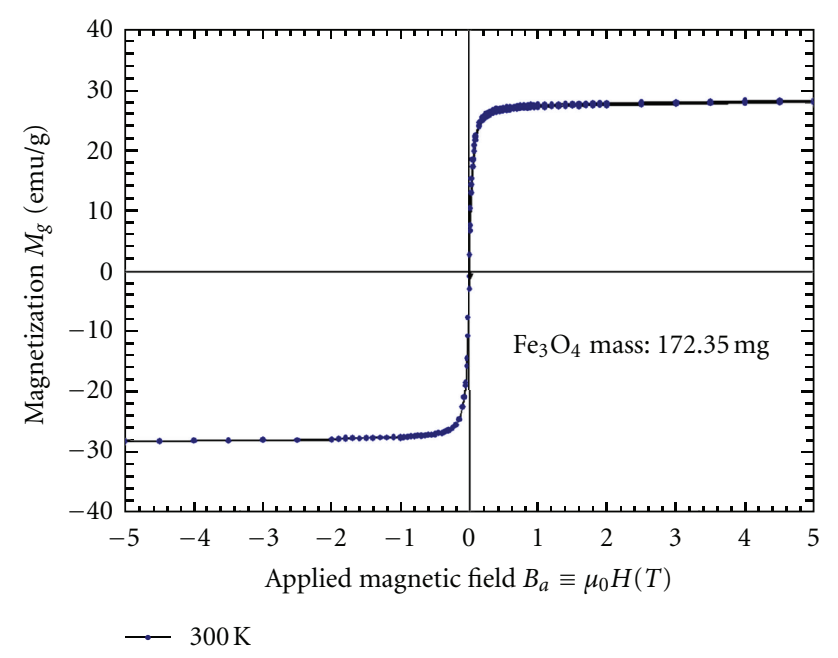

FIgure 5: The SQUID analysis of $\mathrm{TiO}_{2} / \mathrm{Fe}_{3} \mathrm{O}_{4}$ particles.

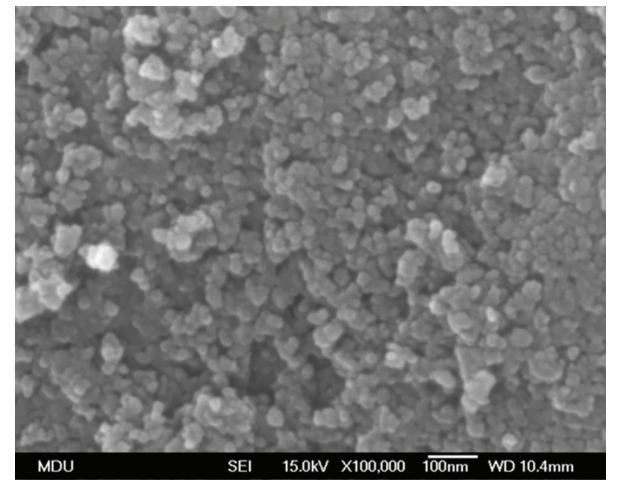

(a)

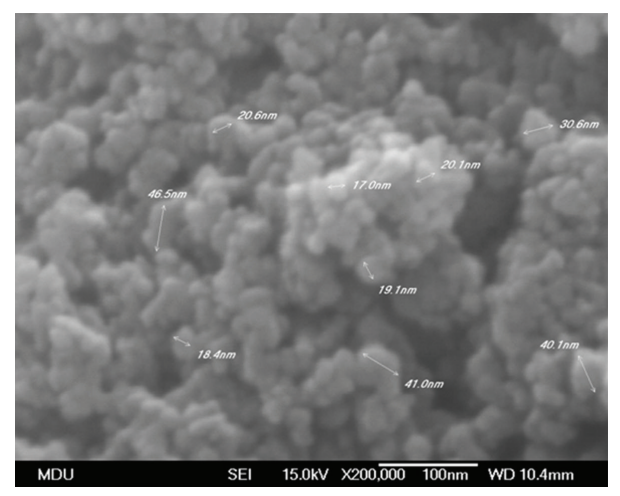

(b)

Figure 6: The SEM image of $\mathrm{TiO}_{2} / \mathrm{Fe}_{3} \mathrm{O}_{4}$ particles.

were obvious variations in the photocatalytic reactions. In general, the yield of hydroxyl radicals in the photocatalytic reaction increases with increasing $\mathrm{pH}$ of the aqueous solution. However, the distribution ratios of the intermediates produced in the solution were directly related to the $\mathrm{pH}$ values. Moreover, the $\mathrm{pH}$ value alters the electrical behavior on the surface of the photocatalyst leading to changes in the absorption and desorption properties and capabilities of

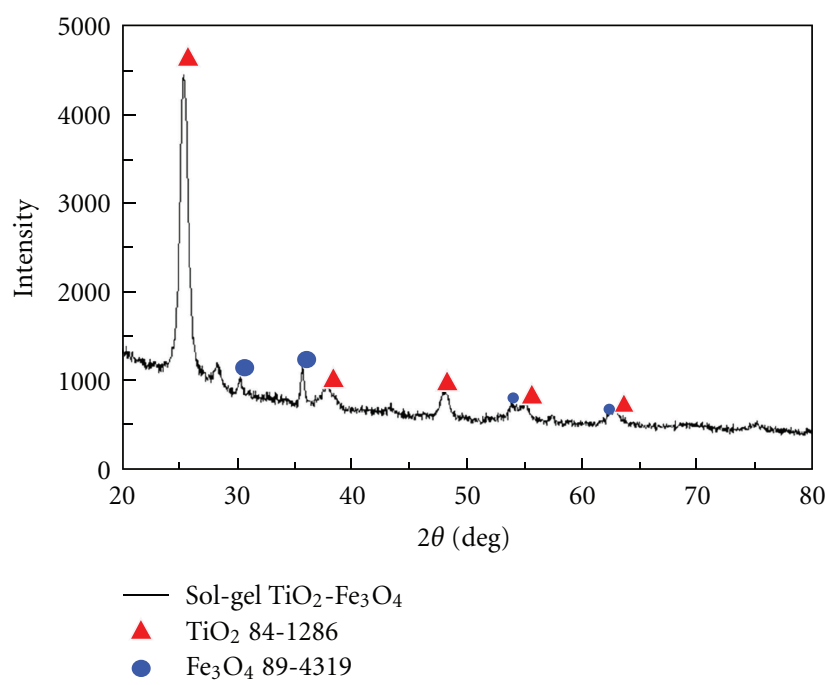

Figure 7: The X-ray diffraction spectrum of $\mathrm{TiO}_{2} / \mathrm{Fe}_{3} \mathrm{O}_{4}$.

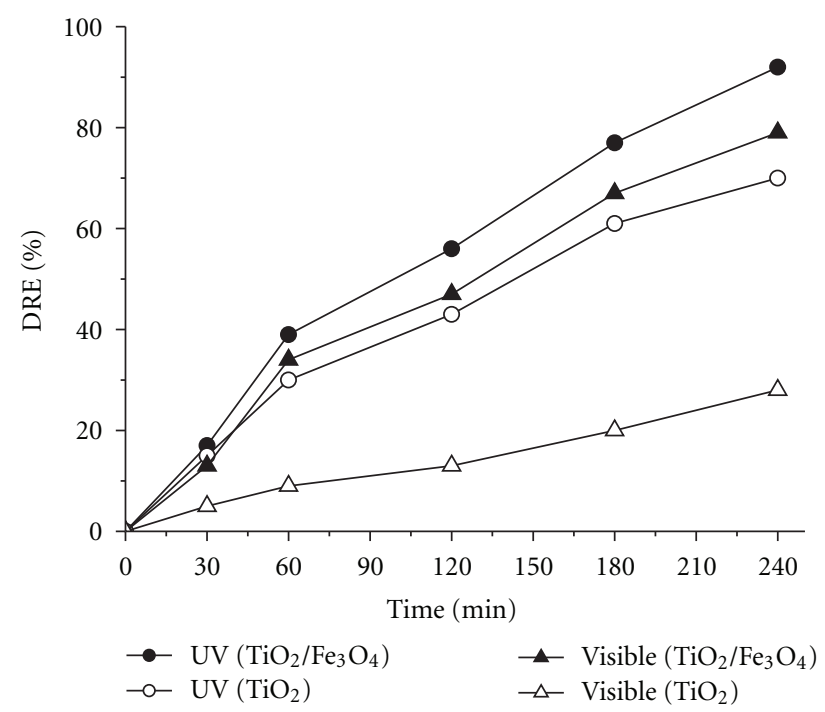

FIgure 8: Comparison of the effect of $\mathrm{TiO}_{2} / \mathrm{Fe}_{3} \mathrm{O}_{4}$ catalyst on the DRE of IPA under the UV-A and VFL irradiation.

the intermediates produced by the catalyst. Therefore, the control of $\mathrm{pH}$ during the operation had significant impact on the efficiency of the overall treatment.

The $\mathrm{pH}_{\text {zpc }}$ value of $\mathrm{TiO}_{2}$ is 6.4. Therefore, the $\mathrm{TiO}_{2}$ surface carries a positive charge at $\mathrm{pH}$ below 6.4. However, more and more oxygen ions dissociate from the $\mathrm{TiO}_{2}$ surface at $\mathrm{pH}$ above 6.4, causing a negative charge to develop on the catalyst surface. The substances formerly attached to the catalyst surface as a result of electrostatic adsorption begin to leave the catalyst under the influence of electric repulsion between the substances and the catalyst, thus lowering the oxidation/reduction rate of the reactants. Therefore, the ionic reactants are more affected by the $\mathrm{pH}$ of the environment due to electrostatic interaction. Figure 9 illustrates the destruction removal efficiency of IPA under the VFL irradiation for 240 minutes of photocatalytic reaction. As can 


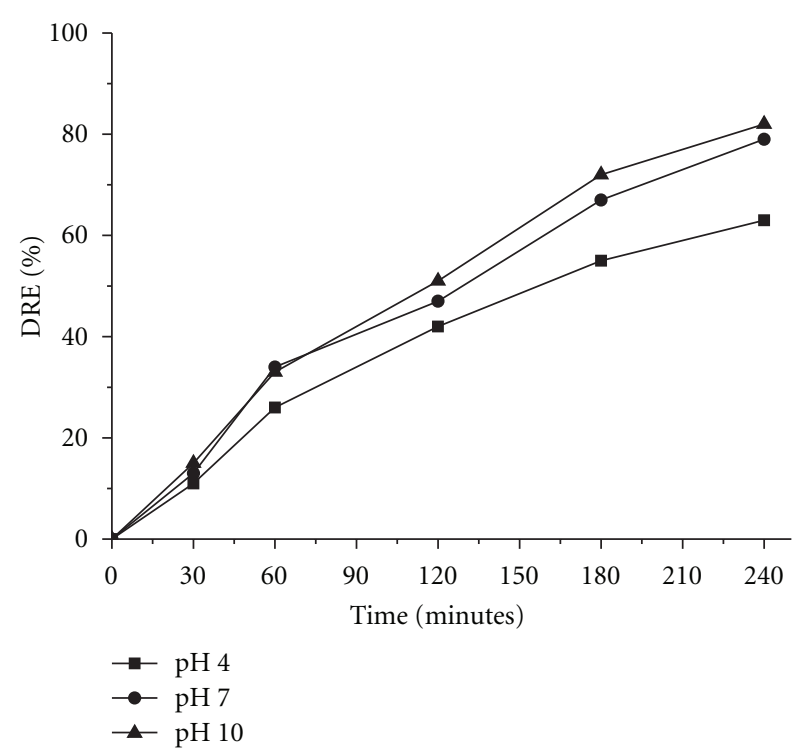

Figure 9: Destruction removal efficiency of IPA at different $\mathrm{pH}$. (VFL, $2 \mathrm{~g} \mathrm{TiO}_{2} / \mathrm{Fe}_{3} \mathrm{O}_{4}$ catalyst, and IPA of $30 \mathrm{mg} \mathrm{L}^{-1}$ ).

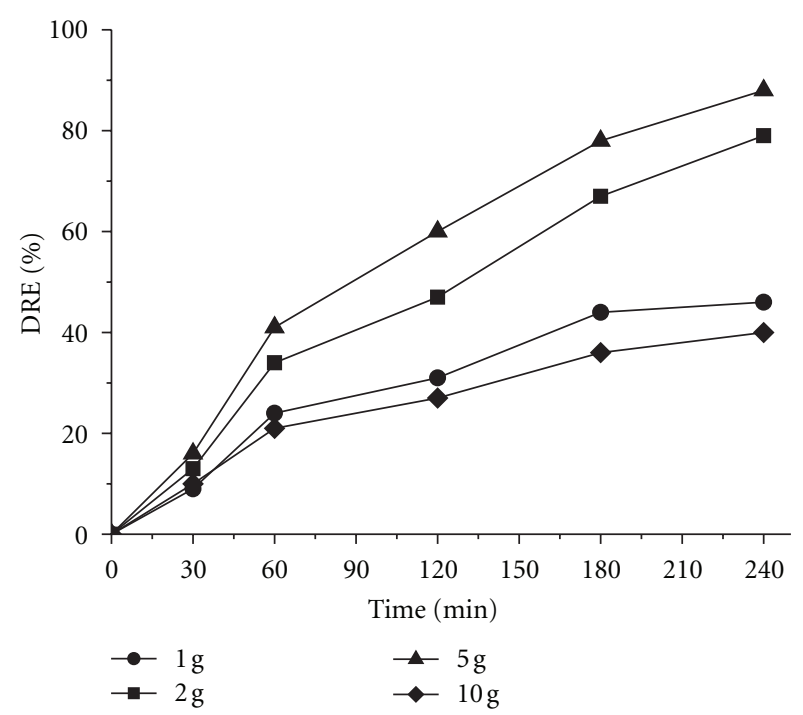

FIgURE 10: Destruction removal efficiency of IPA at different amount of photocatalysts. (VFL, pH of 7 and IPA of $30 \mathrm{mg} \mathrm{L}^{-1}$ ).

be seen, the removal rate of IPA was higher under basic conditions, and the result coincided with previous studies [32].

3.6. Effect of Addition of Photocatalyst. The objective of the present study was to identify the optimal quantity of the $\mathrm{TiO}_{2} / \mathrm{Fe}_{3} \mathrm{O}_{4}$ composite catalyst added according to economic consideration. This part of the experiment was carried out under the following conditions: initial IPA concentration of $30 \mathrm{mg} \mathrm{L}^{-1}, \mathrm{pH} \mathrm{7}$, temperature of $25^{\circ} \mathrm{C}$, and VFL for $240 \mathrm{~min}$. The variations in DRE thus obtained are illustrated in Figure 10. As can be seen, when the photocatalyst added was increased from $1 \mathrm{~g}$ to $5 \mathrm{~g}$, the DRE was improved from

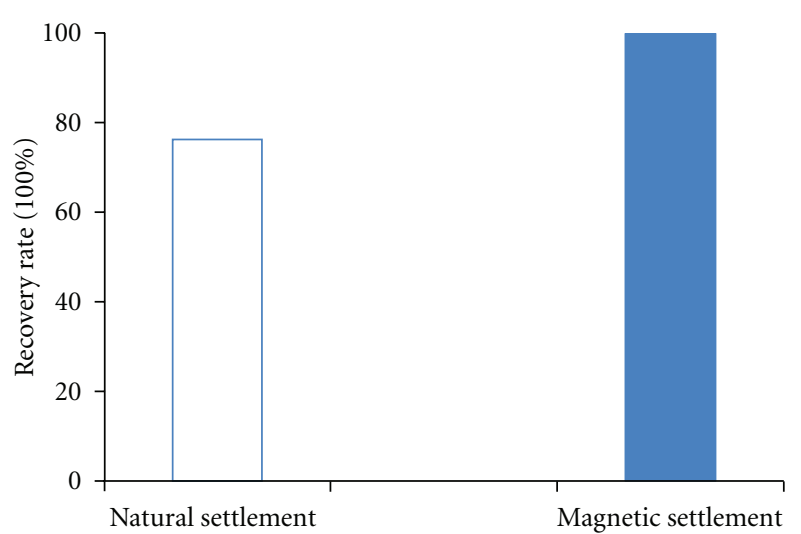

Figure 11: Recovery of $\mathrm{TiO}_{2} / \mathrm{Fe}_{3} \mathrm{O}_{4}\left(3 \mathrm{~g} \mathrm{TiO} / \mathrm{Fe}_{3} \mathrm{O}_{4}\right.$ under 3 minutes settling time).

$46 \%$ to $88 \%$. However, when the amount of the $\mathrm{TiO}_{2} / \mathrm{Fe}_{3} \mathrm{O}_{4}$ composite catalyst added was increased from $5 \mathrm{~g}$ to $10 \mathrm{~g}$, the DRE was reduced. It was speculated that excessive amount of the $\mathrm{TiO}_{2} / \mathrm{Fe}_{3} \mathrm{O}_{4}$ photocatalyst added to the solution caused shielding of the light. Thus, both the light path and amount of $\mathrm{TiO}_{2} / \mathrm{Fe}_{3} \mathrm{O}_{4}$ photocatalyst available for visible light irradiation were reduced, resulting in a decrease in overall treatment efficiency. At the same time, the recovery rate of photocatalyst could reach to $99.8 \%$ as we recollected easily from recycled water using magnet (shown in Figure 11). It is also illustrated that the system of $\mathrm{TiO}_{2} / \mathrm{Fe}_{3} \mathrm{O}_{4}$ has significant efficiency of photodegradation under visible light irradiation and can be used and recycled in the practical wastewater treatment factories in the future.

\section{Conclusions}

Various dopants have been used for $\mathrm{TiO}_{2}$ to absorb visible light. $\mathrm{Fe}_{3} \mathrm{O}_{4}$ was chosen and added during the preparation of $\mathrm{TiO}_{2}$ photocatalystsusing sol-gel method that made $\mathrm{TiO}_{2}$ photocatalytic activity be activated by visible light. In this study, the synthesized $\mathrm{TiO}_{2} / \mathrm{Fe}_{3} \mathrm{O}_{4}$ can be activated by irradiation of UV-A and VFL. No significant photocatalytic activity was lost after being recollected from water using magnet for reusing. $\mathrm{TiO}_{2} / \mathrm{Fe}_{3} \mathrm{O}_{4}$ also demonstrated the DRE of IPA under VFL and resolved $\mathrm{TiO}_{2} / \mathrm{Fe}_{3} \mathrm{O}_{4}$ recovery problem when it was used in the practical wastewater treatment factories. In additional, The prepared $\mathrm{TiO}_{2} / \mathrm{Fe}_{3} \mathrm{O}_{4}$ photocatalyst was identified as anatase, and particle size was about $20 \sim 40 \mathrm{~nm}$ formed by XRD and FE-SEM. In the photodegradation experiments, the results indicated that $40 \sim 88 \%$ DRE reached at different amounts of $\mathrm{TiO}_{2} / \mathrm{Fe}_{3} \mathrm{O}_{4}$, and the best addition amount was $5 \mathrm{~g} \mathrm{TiO}_{2} / \mathrm{Fe}_{3} \mathrm{O}_{4}$ under $\mathrm{pH}$ 10.

\section{References}

[1] T. C. Cheng, K. S. Yao, N. Yeh et al., "Bactericidal effect of blue LED light irradiated $\mathrm{TiO}_{2} / \mathrm{Fe}_{3} \mathrm{O}_{4}$ particles on fish pathogen in seawater," Thin Solid Films, vol. 519, no. 15, pp. 5002-5006, 2011. 
[2] Z. Zhang and J. Gamage, "Applications of photocatalytic disinfection," International Journal of Photoenergy, vol. 2010, Article ID 764870, 11 pages, 2010.

[3] C. Y. Chang, Y. H. Hsieh, L. L. Hsieh, K. S. Yao, and T. C. Cheng, "Establishment of activity indicator of $\mathrm{TiO}_{2}$ photocatalytic reaction-hydroxyl radical trapping method," Journal of Hazardous Materials, vol. 166, no. 2-3, pp. 897-903, 2009.

[4] T. C. Cheng, K. S. Yao, Y. H. Hsieh, L. L. Hsieh, and C. Y. Chang, "Optimizing preparation of the $\mathrm{TiO}_{2}$ thin film reactor using the Taguchi method," Materials and Design, vol. 31, no. 4, pp. 1749-1751, 2010.

[5] J. Anthony, P. A. Fernandez-Ibañez, P. S. M. Dunlop, D. M. A. Alrousan, and J. W. J. Hamilton, "Photocatalytic enhancement for solar disinfection of water: a review," International Journal of Photoenergy, vol. 2011, Article ID 798051, 12 pages, 2011.

[6] K. S. Yao, T. C. Cheng, S. J. Li et al., "Comparison of photocatalytic activities of various dye-modified $\mathrm{TiO}_{2}$ thin films under visible light," Surface and Coatings Technology, vol. 203, no. 5-7, pp. 922-924, 2008.

[7] M. L. Chen and W. C. Oh, "The improved photocatalytic properties of methylene blue for $\mathrm{V}_{2} \mathrm{O}_{3} / \mathrm{CNT} / \mathrm{TiO} \mathrm{O}_{2}$ composite under visible light," International Journal of Photoenergy, vol. 2010, Article ID 264831, 6 pages, 2010.

[8] J. Yu, J. Xiong, B. Cheng, and S. Liu, "Fabrication and characterization of $\mathrm{Ag}-\mathrm{TiO}_{2}$ multiphase nanocomposite thin films with enhanced photocatalytic activity," Applied Catalysis B, vol. 60, no. 3-4, pp. 211-221, 2005.

[9] J. Zhou, Y. Cheng, and J. G. Yu, "Preparation and characterization of visible-light-driven plasmonic photocatalyst $\mathrm{Ag} / \mathrm{AgCl} / \mathrm{TiO}_{2}$ nanocomposite thin films," Journal of Photochemistry and Photobiology A, vol. 223, no. 2-3, pp. 82-87, 2011.

[10] Y. Li, G. Lu, and S. Li, "Photocatalytic transformation of rhodamine $\mathrm{B}$ and its effect on hydrogen evolution over Pt/ $\mathrm{TiO}_{2}$ in the presence of electron donors," Journal of Photochemistry and Photobiology A, vol. 152, no. 1-3, pp. 219-228, 2002.

[11] J. Yu, Y. Hai, and B. Cheng, "Enhanced photocatalytic $\mathrm{H}_{2}$ production activity of $\mathrm{TiO}_{2}$ by $\mathrm{Ni}(\mathrm{OH})_{2}$ cluster modification," Journal of Physical Chemistry C, vol. 115, no. 11, pp. 49534958, 2011.

[12] M. Zhou, J. Yu, S. Liu, P. Zhai, and L. Jiang, "Effects of calcination temperatures on photocatalytic activity of $\mathrm{SnO}_{2} /$ $\mathrm{TiO}_{2}$ composite films prepared by an EPD method," Journal of Hazardous Materials, vol. 154, no. 1-3, pp. 1141-1148, 2008.

[13] G. Dai, J. Yu, and G. Liu, "Synthesis and enhanced visiblelight photoelectrocatalytic activity of p-n junction $\mathrm{BiOI} / \mathrm{TiO}_{2}$ nanotube arrays," Journal of Physical Chemistry C, vol. 115, no. 15, pp. 7339-7346, 2011.

[14] S. M. Alves Jorge, J. J. de Sene, and A. de Oliveira Florentino, "Photoelectrocatalytic treatment of p-nitrophenol using $\mathrm{Ti} / \mathrm{TiO}_{2}$ thin-film electrode," Journal of Photochemistry and Photobiology A, vol. 174, no. 1, pp. 71-75, 2005.

[15] C. H. Shen, C. Y. Chang, and S. L. Lo, "Visible light activated photocatalytic degradation effect of $\mathrm{V}-\mathrm{TiO}_{2}$ on methyl tertbutyl ether," Advanced Materials Research, vol. 255-260, pp. 2705-2709, 2011.

[16] L. L. Hsieh, C. Y. Chang, H. L. Shyu, C. A. Tsou, and H. H. Lo, "The inhibition effect of $\mathrm{TiO}_{2} / \mathrm{Ag}$ thin film on Acinetobacter baumannii," Advanced Materials Research, vol. 123-125, pp. 272-275, 2010.

[17] R. Poliah and S. Sreekantan, "Characterization and photocatalytic activity of enhanced Copper-Silica-loaded Titania prepared via hydrothermal method," Journal of Nanomaterials, vol. 2011, Article ID 239289, 8 pages, 2011.

[18] Y. Tian, D. Wu, X. Jia, B. Yu, and S. Zhan, "Core-shell nanostructure of $\alpha-\mathrm{Fe}_{2} \mathrm{O}_{3} / \mathrm{Fe}_{3} \mathrm{O}_{4}$ : synthesis and photocatalysis for methyl orange," Journal of Nanomaterials, vol. 2011, Article ID 837123, 5 pages, 2011.

[19] C. Y. Chang, Y. H. Hsieh, and Y. Y. Chen, "Photoelectrocatalytic degradation of sodium oxalate by $\mathrm{TiO}_{2} / \mathrm{Ti}$ thin film electrode," International Journal of Photoenergy, vol. 2012, Article ID 576089, 6 pages, 2012.

[20] Q. Xiang, J. Yu, and M. Jaroniec, "Graphene-based semiconductor photocatalysts," Chemical Society Reviews, vol. 41, pp. 782-796, 2012.

[21] S. Liu, J. Yu, and M. Jaroniec, "Anatase $\mathrm{TiO}_{2}$ with dominant high-energy 001 facets : synthesis, properties, and applications," Chemistry of Materials, vol. 23, pp. 4085-4093, 2011.

[22] X. Yu, S. Liu, and J. Yu, "Superparamagnetic $\gamma-\mathrm{Fe}_{2} \mathrm{O}_{3} @ \mathrm{SiO}_{2} @$ $\mathrm{TiO}_{2}$ composite microspheres with superior photocatalytic properties," Applied Catalysis B, vol. 104, no. 1-2, pp. 12-20, 2011.

[23] Y. J. Chang, J. W. Lee, C. H. Lin, C. Y. Chang, Y. C. Lee, and M. Y. Hwa, "Photocatalytic deactivation of airborne microbial cells by the stainless steel sieves with surface coated $\mathrm{TiO}_{2}$ thin films," Surface \& Coatings Technology, vol. 205, no. 1, pp. S328-S332, 2010.

[24] T. C. Cheng, K. S. Yao, N. Yeh et al., "Visible light activated bactericidal effect of $\mathrm{TiO}_{2} / \mathrm{Fe}_{3} \mathrm{O}_{4}$ magnetic particles on fish pathogens," Surface \& Coatings Technology, vol. 204, no. 6-7, pp. 1141-1144, 2009.

[25] M. Y. Chang, Y. H. Hsieh, T. C. Cheng, K. S. Yao, M. C. Wei, and C. Y. Chang, "Photocatalytic degradation of 2,4dichlorophenol wastewater using porphyrin/ $/ \mathrm{TiO}_{2}$ complexes activated by visible light," Thin Solid Films, vol. 517, no. 14, pp. 3888-3891, 2009.

[26] L. Zhao, J. G. Ran, Z. Shu, G. T. Dai, P. G. Zhai, and S. M. Wang, "Effects of calcination temperatures on photocatalytic activity of ordered titanate nanoribbon/SnO2 films fabricated during an EPD process," Journal of Photochemistry and Photobiology A, vol. 2012, Article ID 472958, 7 pages, 2012.

[27] G. Shang, H. Fu, S. Yang, and T. Xu, "Mechanistic study of visible-light-induced photodegradation of 4-chlorophenol by $\mathrm{TiO}_{2-x} \mathrm{Nx}$ with low nitrogen concentration," International Journal of Photoenergy, vol. 2012, Article ID 759306, 9 pages, 2012.

[28] J. Yu and J. Ran, "Facile preparation and enhanced photocatalytic $\mathrm{H}_{2}$-production activity of $\mathrm{Cu}(\mathrm{OH})_{2}$ cluster modified $\mathrm{TiO}_{2}$," Energy \& Environmental Science, vol. 4, no. 4, pp. 13641371, 2011.

[29] J. Yu and B. Wang, "Effect of calcination temperature on morphology and photoelectrochemical properties of anodized titanium dioxide nanotube arrays," Applied Catalysis B, vol. 94, no. 3-4, pp. 295-302, 2010.

[30] J. Yu, G. Dai, and B. Cheng, "Effect of crystallization methods on morphology and photocatalytic activity of anodized $\mathrm{TiO}_{2}$ nanotube array films," Journal of Physical Chemistry C, vol. 114, no. 45, pp. 19378-19385, 2010.

[31] J. N. Zhang, Introduction to Taguchi Quality Engineering, Quality Control Society of the Republic of China, Taiwan, 1989.

[32] K. Y. Cheng, K. S. Yao, H. H. Lo, C. Y. Chang, and P. H. Chen, "Photoelectrocatalytic degradation of isopropyl alcohol by $\mathrm{TiO}_{2} / \mathrm{Ti}$ thin-film electrode," Advanced Materials Research, vol. 123-125, pp. 165-168, 2010. 

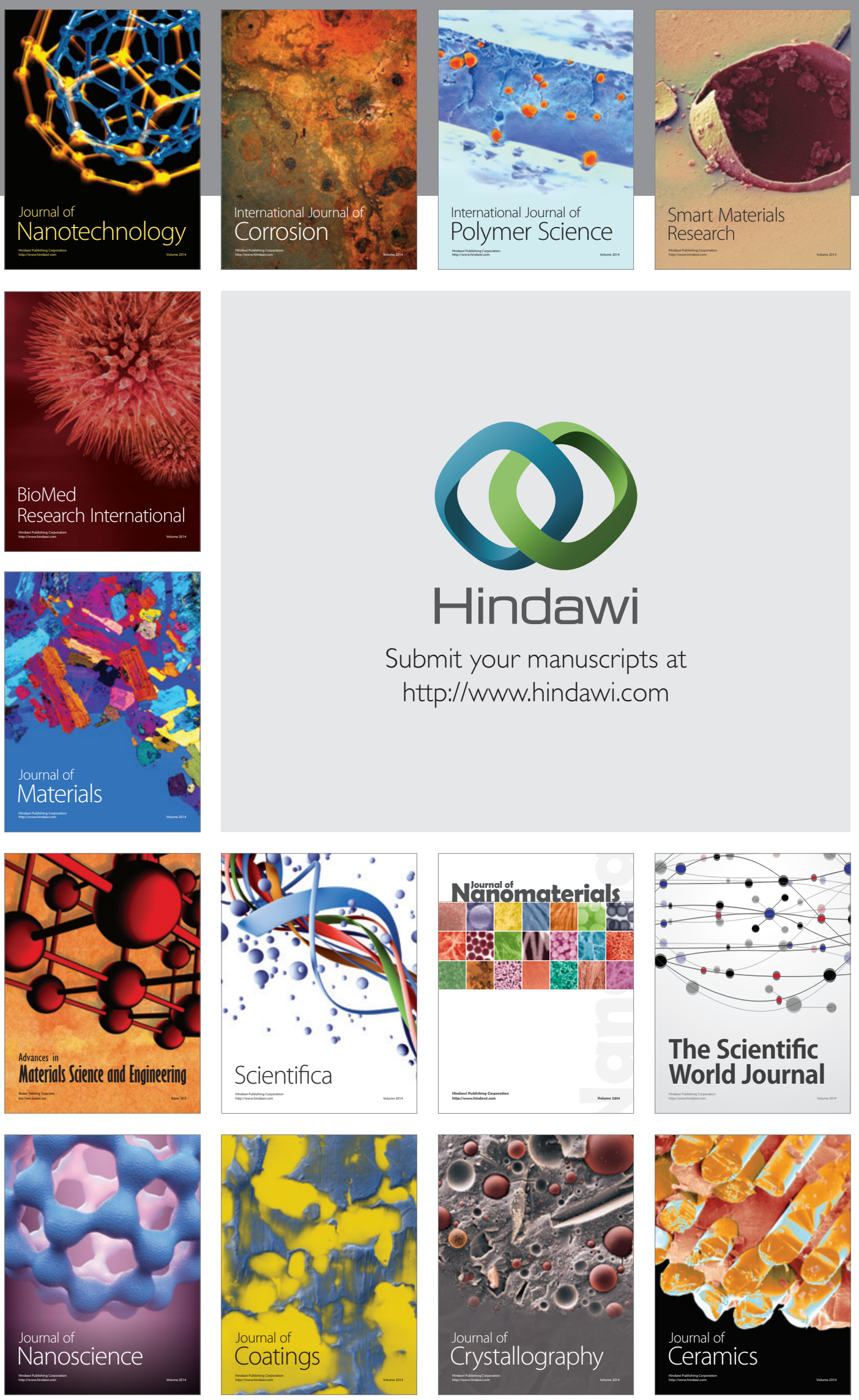

The Scientific World Journal

Submit your manuscripts at

http://www.hindawi.com

\section{World Journal}

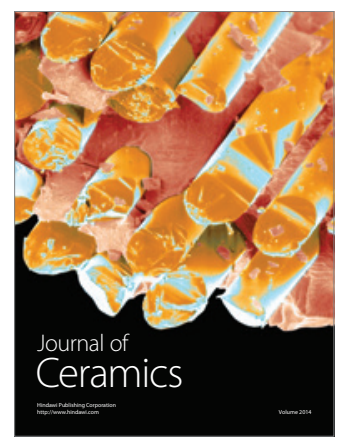

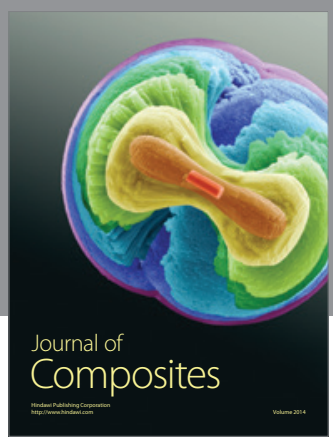
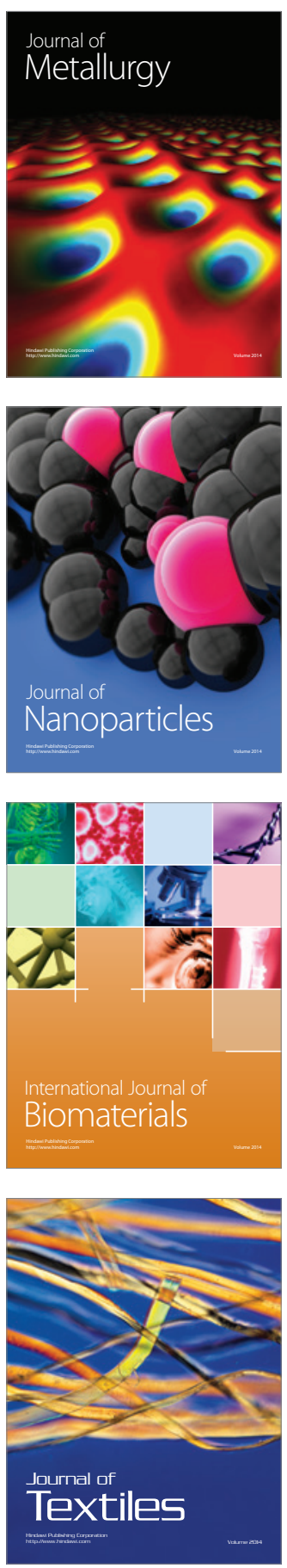